\title{
INFLUENCE OF INDOOR POLLUTION AND PARAMETERS ON HUMAN HEALTH Rositsa Velichkova ${ }^{1}$, Peter Stankov ${ }^{2}$, Radositna A. Angelova ${ }^{3}$, Iskra Simova ${ }^{4}$, Detelin Markov ${ }^{5}$
}

\begin{abstract}
Indoor air quality (IAQ) is an important issue, considering that modern people spend most of their time indoors in houses, workplaces, recreation areas. IAQ has a serious impact on human health, comfort, performance, and wellbeing. In order to minimize the negative consequences, considerable efforts are made to assure the high quality of the indoor air. In the present paper, indoor pollution is analysed in light of its effect on IAQ and human health. The indoor pollutants are due to the presence of higher concentrations of chemical species, physical processes or biologicals in the ambient air.
\end{abstract}

UDC Classification: 628.8, DOI: 10.12955/cbup.v7.1493

Keywords: IAQ, indoor pollution, indoor parameters, air

\section{Introduction}

Indoor air pollutants enters the occupant's body through four different "doors": through the lungs by respiration, through the mucous membranes of the nose and eyes, through the skin, and through the digestive system. The dose depends on the concentration of the pollutants and the exposure period.

Exposure occurs at the place where people often stay, in an area commonly referred to as "microenvironment". Microenvironment is defined as the three-dimensional space where the level of pollutants at a given time is the same. The microenvironment is characterized by a constant statistical concentration of the species.

Given the global environmental classification scheme, including the natural and socio-economic environment, as well as international statistics, it can be concluded that the majority of the world population lives in developing countries.

A significant part of the population in developed countries lives in urban environments and works in the office environment, as the post-industrial era has led to a shift from the manufacturing sector to the service and knowledge sector.

The present paper deals with the problem of indoor air quality (IAQ) in different microenvironments in enclosures.

\section{Indoor pollution}

People are the main reason for the quality of the indoor environment they occupy and, above all, for the indoor air quality. They, with their decisions regarding the construction materials, the interior products, and the building systems (HVAC, water supply and sewerage, electrical) predetermine the presence of different pollutants in the indoor air. In addition to this, people deteriorate the quality of the air in the space they occupy (pollute the indoor air) by their presence, i.e. by the physiological processes taking place in their bodies, which are continuous (metabolism) and discrete (defecation and urination). People also pollute the indoor air through their actions: activities (cooking, bathing, cleaning, insect fighting, etc.) and habits (aromatization, smoking, etc.).

Internal contamination is due to the presence of higher concentrations of chemical species (e.g. carbon monoxide), physical processes or biological pollutants (e.g. dust mites) in the ambient air. Different

\footnotetext{
${ }^{1}$ Technical University of Sofia, Department Hydroaerodymaics and hydraulic machines, Centre for Research and Design in Human Comfort, Energy and Environment (CERDECEN), Sofia, Bulgaria, rositsavelichkova@abv.bg

${ }^{2}$ Technical University of Sofia, Department Hydroaerodynmics and hydraulic machines, Centre for Research and Design in Human Comfort, Energy and Environment (CERDECEN), Sofia, Bulgaria, peter.stankov@abv.bg ${ }^{3}$ Technical University of Sofia, Department of Textiles, Centre for Research and Design in Human Comfort, Energy and Environment (CERDECEN), Sofia, Bulgaria

${ }^{4}$ Technical University of Sofia, Department Hydroaerodynmics and hydraulic machines, Centre for Research and Design in Human Comfort, Energy and Environment (CERDECEN), Sofia, Bulgaria, iskrasimova@gmail.com

${ }^{5}$ Technical University of Sofia, Department Hydroaerodymaics and hydraulic machines, Centre for Research and Design in Human Comfort, Energy and Environment (CERDECEN), Sofia, Bulgaria, detmar@abv.bg
} 


\begin{tabular}{|c|c|c|}
\hline Pollution & Major Sources in Buildings & Health effect \\
\hline Radon & $\begin{array}{l}\text { Related to soil and groundwater, including: } \\
\text { \# rocks under house foundation, \# soil-derived } \\
\text { building materials, and \# water from drilled well }\end{array}$ & $\begin{array}{l}\text { \# No immediate symptoms. } \\
\text { \# Lung cancer. Higher risk } \\
\text { for smokers. }\end{array}$ \\
\hline $\begin{array}{l}\text { Biological Contaminants } \\
\text { (molds, mildews and } \\
\text { fungi, bacteria, viruses, } \\
\text { dust mites) }\end{array}$ & $\begin{array}{l}\text { Related to house dust: } \\
\text { \# infected humans or animals, } \\
\text { \# bedding, } \\
\text { \# poorly maintained humidifiers, dehumidifiers \& air } \\
\text { conditioners, } \\
\text { \# wet or moist surfaces, } \\
\text { \# carpets, home textiles and furnishings }\end{array}$ & $\begin{array}{l}\text { \# Allergies and asthma } \\
\text { \# Headaches } \\
\text { \# Eye, nose and throat } \\
\text { irritation } \\
\text { \# Colds, flu, and } \\
\text { pneumonia }\end{array}$ \\
\hline Carbon Monoxide (CO) & $\begin{array}{l}\text { Related to heating devices and combustion processes } \\
\text { (furnaces, water heaters, fuel-fired space heaters): } \\
\text { \# wood or coal stoves, } \\
\text { \# fireplaces, } \\
\text { \# cook tops and ovens, } \\
\text { \# charcoal grills, } \\
\text { \# engines (gasoline, diesel), } \\
\text { \# tobacco smoke }\end{array}$ & $\begin{array}{l}\text { \# Headaches, drowsiness, } \\
\text { dizziness } \\
\text { \# Impairment of human } \\
\text { respiration, vision \& brain } \\
\text { functioning, nausea, mental } \\
\text { confusion } \\
\text { \# Symptoms often masked } \\
\text { as flu symptoms } \\
\text { \# Very high levels can } \\
\text { cause death }\end{array}$ \\
\hline Nitrogen Oxides & Related to heating devices and combustion processes & $\begin{array}{l}\text { \# Respiratory tract } \\
\text { problems } \\
\text { \# Lungs injuries }\end{array}$ \\
\hline Sulfur Dioxide & Related to heating devices and combustion processes & $\begin{array}{l}\text { \# Irritation of eyes and nose } \\
\text { \# Respiratory injuries }\end{array}$ \\
\hline $\begin{array}{l}\text { Respirable Suspended } \\
\text { Particulates (RSP) }\end{array}$ & $\begin{array}{l}\text { Related to heating devices and combustion processes, } \\
\text { as well as house dusts: \# wood or coal stoves, \# } \\
\text { fireplaces, \# unvented kerosene space heaters, \# gas- } \\
\text { fired tops and furnaces, \# gas-fired ranges and water } \\
\text { heaters, \# vacuum cleaners, \# soap powders and } \\
\text { cleaning sprays, \# tobacco smoke }\end{array}$ & $\begin{array}{l}\text { \# Irritation of eyes, nose, } \\
\text { and throat } \\
\text { \# Respiratory infections } \\
\text { \# Bronchitis } \\
\text { \# Emphysema } \\
\text { \# Lung cancer }\end{array}$ \\
\hline $\begin{array}{l}\text { Environmental Tobacco } \\
\text { Smoke }\end{array}$ & $\begin{array}{l}\text { Related to all types of smoking: \# cigarettes, \# cigars } \\
\text { and \# pipes }\end{array}$ & $\begin{array}{l}\text { \# No immediate symptoms } \\
\text { \# Chest, abdominal and } \\
\text { lung cancers and asbestosis }\end{array}$ \\
\hline $\begin{array}{l}\text { Volatile Organic } \\
\text { Compounds (VOCs) }\end{array}$ & $\begin{array}{l}\text { Related to house maintenance and cleaning, as well as } \\
\text { indoor design: \# aerosol sprays and deodorizers, hair } \\
\text { sprays, perfumes, \# solvents and glues, \# cleaning and } \\
\text { washing agents, \# fabric softeners, \# paints, \# } \\
\text { pesticides, moth repellents, \# dry-cleaned clothing, \# } \\
\text { mothballs, \# tobacco smoke }\end{array}$ & $\begin{array}{l}\text { \# Irritation of eyes, nose, } \\
\text { and throat } \\
\text { \# Headaches } \\
\text { \# Loss of coordination, } \\
\text { confusion } \\
\text { \# Liver, kidneys, and brain } \\
\text { injuries } \\
\text { \# Various types of cancer }\end{array}$ \\
\hline Formaldehyde & $\begin{array}{l}\text { Related to house products, derived from cellulose and } \\
\text { their mounting: \# pressed wood products (plywood, } \\
\text { paneling, particle board), \# urea-formaldhyde wall } \\
\text { insulation foam, \# textiles in the indoors (carpets, } \\
\text { curtains, draperies, upholsteries), \# paper products, } \\
\text { \# some personal care products, } \\
\text { \# tobacco smoke }\end{array}$ & $\begin{array}{l}\text { \# Allergic reactions (wide } \\
\text { range of sensitiveness) } \\
\text { \# Irritation of eyes, nose, } \\
\text { and throat } \\
\text { \# Nausea, dizziness, } \\
\text { coughing } \\
\text { \# Headaches } \\
\text { \# Cancer }\end{array}$ \\
\hline Lead & $\begin{array}{l}\text { Related to sources of lead in nature and houses: \# } \\
\text { lead-based paints and dust from them, } \\
\text { \# water from lead or lead-soldered pipes, \# soil near } \\
\text { lead production plants or highways, \# working with } \\
\text { stained glass, \# lead-glazed ceramic ware, \# some } \\
\text { medicines }\end{array}$ & $\begin{array}{l}\text { \# Damage to brain, kidneys, } \\
\text { and nervous system } \\
\text { \# Slowed growth } \\
\text { \# Behavioral and learning } \\
\text { problems } \\
\text { \# Hearing loss } \\
\text { \# Anemia } \\
\text { \# Large doses can be fatal }\end{array}$ \\
\hline
\end{tabular}


types of indoor pollution and its major sources are given in Table 1 (Angelova, 2015; Simova et. al., 2006; Markov et. al., 2014; Simova, 2015; ECA Report 10, 1991; Emenius, 2004; Sundell, 1994; 1999)

\section{Indoor parameters}

The internal balance of the human body, including the thermophysiological balance, is largely dependent on external conditions. The microclimate of the room in which a person is located for a long time plays a significant role in the formation of immunity, efficiency, the ability to relax and unwind comfortably. The state of the internal environment of the building can not only fruitfully affect human health but also have a negative impact. Thus, the longer people stay in a non-ventilated room, the more the room affects the proper work of the body.

The microclimate of any premises is characterised by air temperature, relative humidity and air velocity. 1. The temperature of the room is the most important indicator of comfort. The relative humidity also depends on the temperature. Low temperatures provoke the release of heat by the human body, which requires thermophysiological reactions, many of them related to discomfort, detention of reaction, sleepiness, and increment of the mistakes. If a low-quality heating equipment is installed in the room, then people will constantly suffer from cold related discomfort and diseases (cold, cough, proclivity to infections).

High temperatures (over $27^{\circ} \mathrm{C}$ ) in the indoor environment also provoke problems, related to the thermophysiological reaction of the body. The release of the excessive heat is accompanied by removing salt from the body. The joint effect of the thermophysiological responses and the changes in the watersalt balance leads to a different impediment of many systems in the human body. The result is thermal discomfort, decreased attention and an increase in mistakes.

2. Relative humidity of indoor air is a factor that depends, to a large extent, on temperature. If there are no installed humidifiers in the room, then the higher the temperature, the drier the air will be. A healthy person, once in a room with dry air, will feel discomfort in 10-15 minutes. If a person has a cold, he will cough. Moderately moist air (40-60\%) will create comfortable conditions for work and rest. In winter, it helps to strengthen the immune system, as it does not allow the mucous to dry out and become vulnerable to viruses. In the summer, with comfortable humidity, it is easier to tolerate heat, maintain healthy skin, etc.

3. The velocity of the air is a factor of the microclimate that affects the body in different ways. For example, at temperatures up to $33-35{ }^{\circ} \mathrm{C}$, the air velocity of $0.15 \mathrm{~m} / \mathrm{s}$ is accepted as comfortable, since the air has a refreshing effect. In a temperature environment of above $35^{\circ} \mathrm{C}$, however, an opposite effect of discomfort appears for the same value of the air velocity (Ordinance RD-07-3 / 18.07.2014).

Table 2 summarizes the minimal microclimate requirements for workplaces in Bulgaria (Ordinance RD07-3/ 18.07.2014).

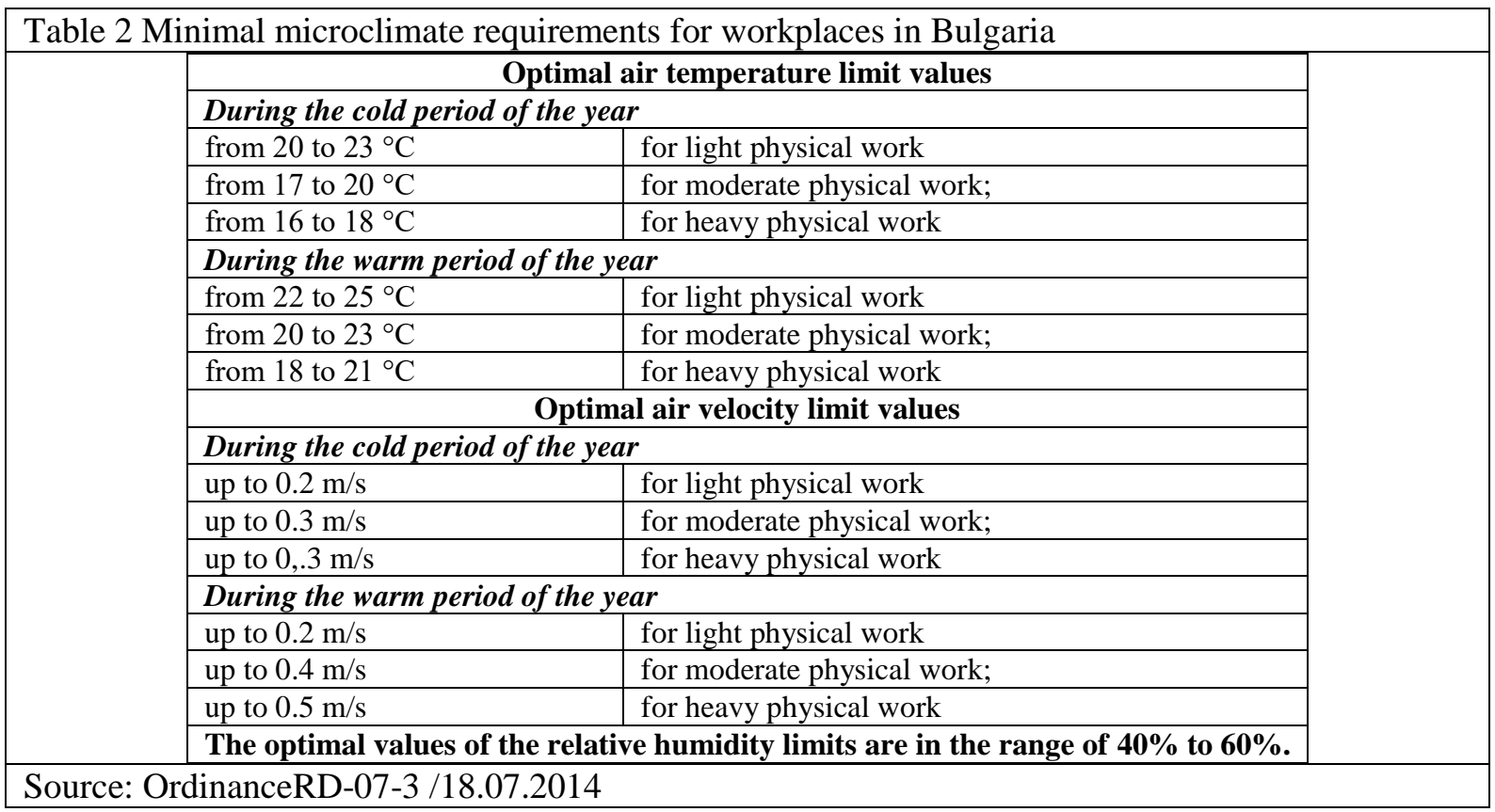




\section{Effects of Exposure to Contaminated Air}

The effect of an individual's exposure to room contamination depends mainly on the nature of the pollutants and the duration of the exposure. Response time after exposure is an essential factor in the assessment of the effect. Immediately after the exposure, acute effects such as inflammation, fatigue, headaches and dizziness occur. This is usually due to exposure to biological pollutants, emissions from building materials, but most often due to incorrect ventilation of the indoor space.

In response to long-term exposure or repeated exposure, chronic effects are manifested (cancer is one of the severe examples). Pollutants include tobacco smoke, radon, benzene, and asbestos.

Effects without serious health effects are the discomfort and the reduction in performance caused by changes in the physical parameters of indoor air.

In general, the umbrella concept is used to integrate the appearance of acute effects from exposure to contaminated indoor premises, "sickness syndrome". As a result of incorrect ventilation and the accumulation of gaseous contamination and/or accumulations of biological pollutants in enclosures, the occupants of the building report a number of complaints for which there is no apparent reason, and the medical tests do not reveal any particular anomalies. Symptoms are present when people are in the building but disappear when they leave. But they usually lead to absenteeism or reduced work abilities and effectiveness of the exposed person. The effects of the indoor air parameters on human health are summarized in Figure 1.

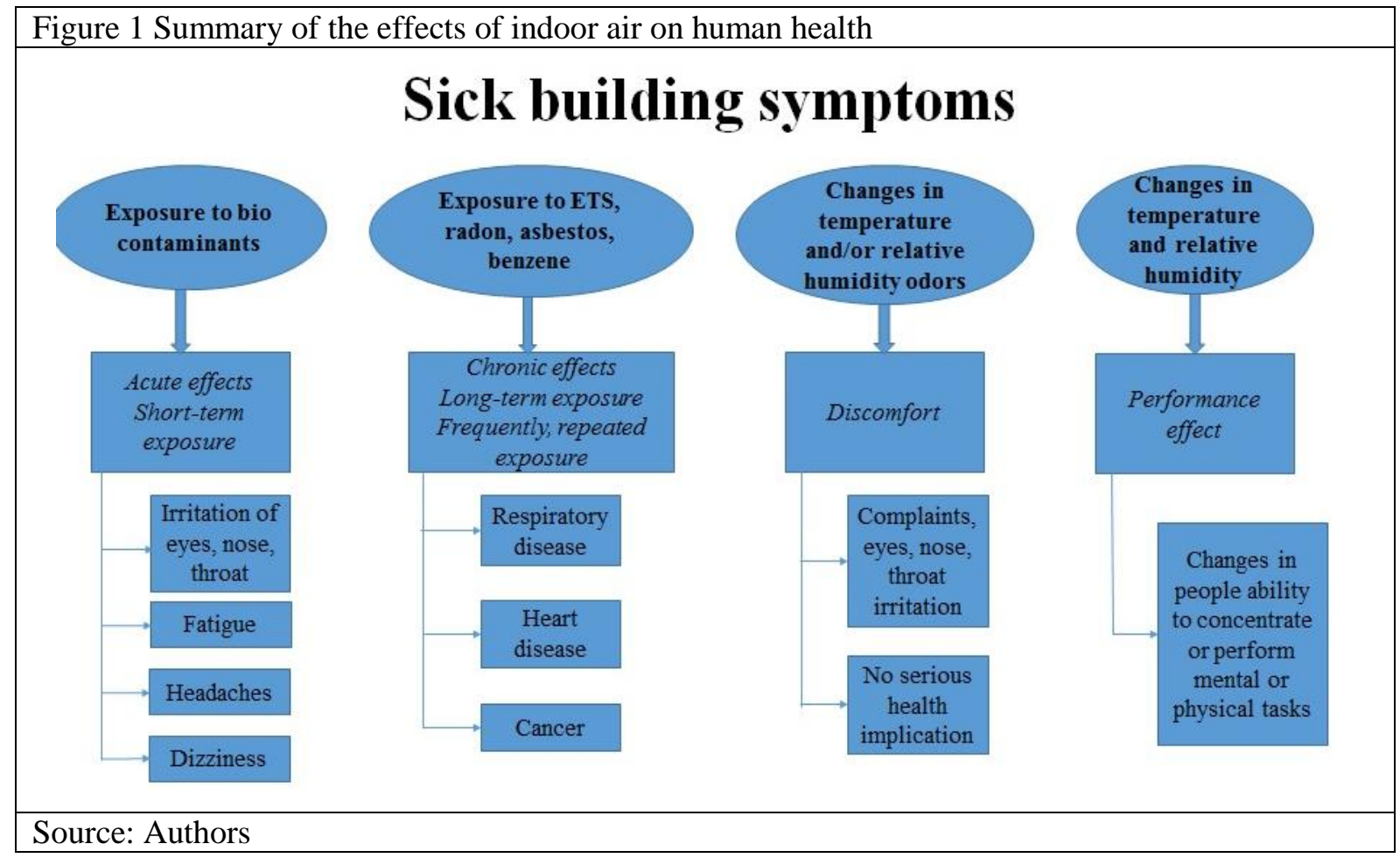

\section{Conclusion}

It is challenging to assess the risk for human health indoors, as the indoor air may contain a vast number of chemicals, biological contaminants, and particulates with potential hazardous effect. At the same time, IAQ is affected by the ventilation scheme (natural or forced ventilation), building characteristics, cleaning habits, occupancy, and cultural peculiarities, as well as the outdoor environment and climate conditions.

There are a lot of studies on the effect of indoor pollutants on human health, but the data to appropriately assess the risk for human health in a particular indoor environment is somewhat limited. More specific information has to be gathered for the health effect due to microbes and particles in terms of their type and level of human exposure. Carbon monoxide, nitrogen oxides, benzene, formaldehyde are of special concern as they have a significant potential to affect human health. Volatile organic compounds, ejected 
by several objects indoors, need special attention and broader research as there are many complex sources of them, secondary emissions and emissions of ultrafine particles.

The joint effect of higher concentrations of carbon dioxide $\left(\mathrm{CO}_{2}\right)$ and other indoor air pollutions also need special attention, as they can have an impaired impact on work performance and increased discomfort that may lead to health-related issues.

\section{Acknowledgements}

This study is part of the project "The Human as a Physiological Source of Deterioration of the Air" Quality and Comfort Conditions in Occupied Non-Industrial Indoor Environments ", DN17 /12/12.12.2017, funded by Bulgarian Science Fund of the Ministry of Education and Science.

\section{References}

Al horr Y., Arif, M., Katafygiotou, M., Mazroei, A., Kaushik, A., \& Elsarrag, E. (2016). Impact of indoor environmental quality on occupant well-being and comfort: A review of the literature. International Journal of Sustainable Built Environment, 5(1), 1-11. https://doi.org/10.1016/j.jjsbe.2016.03.006

Angelova, R. A. (2015). Textiles and human thermophysiological comfort in the indoor environment. CRC Press, Boca Raton, USA. https://doi.org/10.1201/b19118

ECA Report 10(1991): Effects of Indoor Air Pollution on Human Health, European Concerted Action "Indoor Air Quality \& Its Impact on Man", Luxembourg, Office for Publications of the European Communities.

Emenius G., M. Svartengren, J. Korsgaard, L. Nordvall, G. Pershagen, M. Wickman (2004), Building characteristics, indoor air quality, and recurrent wheezing in very young children (BAMSE), Indoor Air; 14: 34-42. https://doi.org/10.1046/j.16000668.2003.00207.x

Kosonen, R., \& Tan, F. (2004). The effect of perceived indoor air quality on productivity loss. Energy and Buildings, 36(10), 981-986. https://doi.org/10.1016/j.enbuild.2004.06.005

Markov D., Stankov P., Simova I., Ivanov M., Kehayova N., Georgiev E. (2014). On the Influence of Indoor Temperature on Occupant's Performance, Ruse University Science Works, October, vol. 53, series 1.2, pp. 159 - 164, ISSN1311-3321.

Ordinance RD-07-3 of 18.07.2014 On the minimum requirements for the microclimate of workplaces.

Simova I. (2015). "On the indoor environment impact on occupants comfort and performance” Ruse University Science Works, October 2015, vol. 54, series 1.2, pp. 179 - 185, ISSN 1311-3321.

Simova I., Markov D., Kehayova N., Angelova R.A., Stankov P. (2016). "Experimental study on the indoor environment quality and students' performance in a classroom" Ruse University Science Works, October 2016, vol. 55, series 1.2, pp. 201 - 207, http://conf.uni-ruse.bg/bg/docs/cp16/1.2/1.2-38.pdf.

Sundell J.(1994), On the association between building ventilation characteristics, some indoor environmental exposures, some allergic manifestations and subjective symptom reports, Indoor Air Supplement. https://doi.org/10.1111/j.16000668.1994.tb00031.x

Sundell J.(1999), Indoor Environment and Health, Stockholm, National Board of Health and Welfare.

Tham, K. W. (2016). Indoor air quality and its effects on humans-A review of challenges and developments in the last 30 years. Energy and Buildings, 130, 637-650. https://doi.org/10.1016/j.enbuild.2016.08.071

Wyon, D. P. (2004). The effects of indoor air quality on performance and productivity. Indoor air, 14(7), 92-101. https://doi.org/10.1111/j.1600-0668.2004.00278.x 